\title{
Traffic lights for crop-based biofuels
}

Ben Phalan

Department of Zoology, University of Cambridge, Cambridge CB2 3EJ, UK

Email: btp22@cam.ac.uk

Nobody likes to have limits put on their freedom. However, in all areas of life, there is recognition that such limits can be useful, not least because they prevent one man's private freedoms from imposing unacceptable costs on others. Drivers consent to traffic laws and speed limits that constrain their behaviour, because the inconvenience of having to slow down is an acceptable price to pay if it reduces the number of pedestrians killed and injured.

How is this relevant to biofuels? There are many different kinds of biofuels, including some with considerable potential to generate cleaner energy and boost rural economies, but also others which under some conditions pose an unacceptable risk of causing harm [1]. The positive and negative effects of biofuels depend not only on what feedstock is used, but also on how that feedstock is produced, how (if at all) it affects land-use change, and to what extent its production is scaled up. For biofuels to deliver on their promise of contributing to a better society, they need to be encouraged within sensible limits, and with effective safeguards.

According to a recent commentary in this journal, "ethanol is by definition sustainable" [2]. One might as well say that crossing a road is by definition safe. It might be safe if the correct institutions (speed limits and traffic lights) are in place and functioning as intended, but it could be very unsafe if not. Control of land-use change associated with biofuel production in many countries today resembles control of traffic in an anarchic state: even where there are traffic laws, they are rarely observed. As a result, biofuels are getting a bad press, in particular where inadequate or incompetent land-use planning has allowed large-scale replacement of habitats such as tropical forests.

Deforestation is nothing new, and biofuel crops are far from being the main culprit: other sectors, notably food crops, livestock and logging, have accounted for larger areas being cleared in the past [3]. However, the spotlight that has been placed on biofuels is warranted, for four reasons. The first is that if the greenhouse gas savings from replacing fossil fuels with biofuels are too often reversed by land-use change emissions, one of the main justifications for producing biofuels is fatally undermined [4]. The same argument carries less weight in relation to food crops. Analysis of lifecycle emissions is complicated and controversial, but defining system boundaries to exclude land-use change would be like excluding traffic from an analysis of how safe it is cross the road.

The second reason is that demand elasticity for crop-based biofuels is greater than that for staple foods, so production of biofuel crops could grow much more rapidly than that of food crops unless appropriate limits are imposed. Most increases in crop production now are coming from increases in land-use efficiency rather than land-use expansion [5]. Nevertheless, habitat destruction caused by expansion of food and feed crops (as well as water pollution from fertiliser run-off, and abstraction of water from dwindling aquifers) continues to cause serious environmental problems [6]. Unless it is properly planned for, and at present it is not, biofuel crop expansion will add further to those problems.

The third reason biofuels are different is that new technologies are opening up a wide new range of potential feedstock crops, many of which are likely to become costly invasive species $[7,8]$. The development of cellulosic and algal biofuels is likely to encourage an increased rate of introduction of alien species around the world. The traits that make these species desirable biofuel feedstocks (e.g., rapid growth rates and competitive ability, wide tolerances, abundant seed production, resistance to pests and diseases) are also traits that predispose them to becoming invasive [14]. A "polluter-pays" approach, requiring those who introduce invasive species to pay for any future control costs, is one mechanism for assigning responsibility, whether plants have been introduced as biofuel feedstocks or for other purposes [9].

The fourth reason to focus on biofuels is one of opportunity. Reforming food production is necessary, but can happen only slowly and reactively in the face of entrenched special interests. Production of 
biofuel crops (particularly cellulosic crops and algae) is newer, and there is more scope for proactive measures to solve problems before they become too serious to ignore. The contradiction of having one set of rules for a crop grown for biofuel, and another for exactly the same crop grown for human consumption, should be used as an argument for improving land-use planning and standards across the entire agricultural sector, not to weaken biofuels standards.

One measure which has been suggested would be a system of "traffic lights" to support strategic land-use planning [15]. This would involve mapping "red" zones, where biofuel and other crops would not be appropriate (e.g., areas with high carbon stocks or concentrations of threatened or endemic biodiversity) and "orange" zones, where they might be. "Green" areas could then be identified within the orange zones, using Strategic Environmental Assessment and - for commercial-scale projects site-based Environmental and Social Impact Assessments.

Such an approach would minimise uncertainty for investors and agriculturalists by keeping biofuels out of places where they would be most likely to cause damage (and provoke controversy), and would help to provide some assurance of genuine environmental benefits for citizens and governments. It would help those involved in the development of new biofuels industries - be they researchers, civil servants or farmers - to know that their work was contributing to a solution rather than a problem. It would disappoint some of the more optimistic (but unrealistic) expectations regarding expansion of crop-based biofuels, but it would also help to encourage innovation in a more productive direction: towards technologies and feedstocks that demand little or no land, and which minimise other environmental externalities. Some exciting possibilities already exist, particularly technologies which integrate biofuel production with waste disposal and remediation $[10,11]$.

Voluntary certification schemes have an important role to play, especially because many governments have been unable or unwilling to provide leadership. There is a plethora of different organisations, roundtables and partnerships, each working on a different subset of the issues [e.g., 16,17]. This fragmented approach has probably been useful in allowing a wide range of solutions to be explored, but there is a need for global co-ordination. In the long run, a convergence of standards, implemented in the spirit of continuous improvement will be in everyone's best interest. Such standards will need to deliver on several key fundamentals if they are to avoid becoming mired in accusations of greenwash: transparency; fair governance structures in which environmental, social and commercial interests are given equal weight; ability to address risks from specific crops in specific places as well as overarching principles; and independent and robust implementation, auditing and enforcement [12]. In the short term, the various voluntary schemes are useful in blazing the trail towards what should eventually become the industry standard.

Countries and companies that spot this trend early will be at an advantage. Those that fail to do so are liable to face increasing problems finding finance, as investors and banks pay more attention to reputational risk, and finding markets, as consumer lobby groups demand greater transparency about where and how products are produced. As Hatcher [13] notes, "losing the trust of stakeholders can be fatal". Nobody wants algae or cellulosic biofuels to take over from palm oil as a poster-child for habitat loss and deforestation. If that unwelcome scenario is to be avoided, some serious thinking about how to design sensible safeguards and limits within which these new feedstocks can be developed is needed sooner rather than later.

Financial \& competing interests disclosure

This editorial was written while the author was a Raymond and Beverly Sackler research fellow at Churchill College, Cambridge, working on research funded by the Isaac Newton Trust and the RSPB. $\mathrm{He}$ assumes all responsibility for the opinions expressed. No writing assistance was utilized in the production of this manuscript.

\section{Bibliography}

1 Tilman D, Socolow R, Foley JA, et al. Beneficial biofuels-the food, energy, and environment trilemma. Science 325(5938), 270-271 (2009). 
2 de Gorter H. Controversy over indirect land use change and the US sustainability standard for ethanol production is misplaced. Biofuels 1(1), 23-25 (2010).

3 Gibbs HK, Ruesch AS, Achard F, et al. Tropical forests were the primary sources of new agricultural land in the 1980s and 1990s. Proc Natl Acad Sci USA 107(38), 16732-16737 (2010).

4 Fargione J, Hill J, Tilman D, Polasky S, Hawthorne P. Land clearing and the biofuel carbon debt. Science 319(5867), 1235-1238 (2008).

5 FAO. The State of Food and Agriculture 2008. Biofuels: prospects, risks and opportunities. Food and Agriculture Organization of the United Nations, Rome, Italy (2008).

6 Foley JA, DeFries R, Asner GP, et al. Global consequences of land use. Science 309(5734), 570574 (2005).

7 Chimera CG, Buddenhagen CE, Clifford PM. Biofuels: the risks and dangers of introducing invasive species. Biofuels 1(5), 785-796 (2010).

8 Pimentel D, Zuniga R, Morrison D. Update on the environmental and economic costs associated with alien-invasive species in the United States. Ecological Economics 52(3), 273-288 (2005).

9 Buddenhagen CE, Chimera C, Clifford P. Assessing Biofuel Crop Invasiveness: A Case Study. PLOS ONE 4(4), e5261 (2009).

10 Shi AZ, Koh LP, Tan HTW. The biofuel potential of municipal solid waste. GCB Bioenergy 1(5), 317-320 (2009).

11 Kuzovkina YA, Quigley MF. Willows Beyond Wetlands: Uses of Salix L. Species for Environmental Projects. Water Air Soil Pollut. 162(1-4), 183-204 (2005).

12 Kaphengst T, Ma MS, Schlegel S. At a tipping point? How the debate on biofuel standards sparks innovative ideas for the general future of standardisation and certification schemes. Journal of Cleaner Production 17(S1), S99-S101 (2009).

13 Hatcher M. New corporate agendas. J. Publ. Aff. 3(1), 32-38 (2003).

\section{Websites}

14 United Nations Environment Programme. Gain or pain? Biofuels and invasive species (2010). http://www.unep.fr/energy/bioenergy/issues/pdf/issue\%20paper\%203\%20\%20invasive\%20species_GBEP\%20FINAL.pdf

$15 \mathrm{IUCN} /$ Shell. Removing barriers to the implementation of more sustainable biofuels. Key messages and proposed actions from the joint IUCN-Shell workshop held in Gland, Switzerland, 28-29 May 2009. (2009).

http://cmsdata.iucn.org/downloads/removing_barriers_biofuels_workshop_report_web.pdf

16 Roundtable on Sustainable Biofuels. http://rsb.epfl.ch/

17 Global Bioenergy Partnership. http://www.globalbioenergy.org/ 